Original Research

\title{
Biomass Effect on Soil Organic Carbon in Semi-Arid Continental Conditions in Central Turkey
}

\author{
Gökhan Büyük ${ }^{1 *}$, Erhan Akça², Takashi Kume ${ }^{3}$, Takanori Nagano ${ }^{4}$ \\ ${ }^{1}$ Adiyaman University, Faculty of Agriculture Science and Technologies, Kahta, Adiyaman, Turkey \\ ${ }^{2}$ Adiyaman University, Technical Programs, Adiyaman, Turkey \\ ${ }^{3}$ Department of Rural Engineering, Ehime University, Matsuyama City, Japan \\ ${ }^{4}$ Department of Agricultural Engineering and Socio-Economic Graduate School of Agricultural Science, \\ Kobe University, Japan
}

Received: 8 July 2019

Accepted: 25 September 2019

\begin{abstract}
Organic carbon in soil represents plant, animal and microbial origin materials associated with mineral fractions in different phases of stabilization and decomposition. Following the combatting of desertification that lasted for almost 60 years in Karapınar District located in the Konya Closed Basin of central Turkey, this study was conducted to monitor the change in organic carbon dynamics of soil and vegetation in different land uses. The research revealed a relatively high ratio of soil organic carbon in preserved soils, but the average value was below 14.5 ton $\mathrm{C} / \mathrm{ha}$. This low value has a negative impact on many of the processes of maintaining soil quality.

Increasing the amount of organic matter will ensure that carbon dioxide, the leading greenhouse gas in the atmosphere, is held in soil. With this in mind, fallow, use of excess fertilizers of nitrogen and over-irrigation must be avoided, and legumes such as vetch and Hungarian vetch cultivation is recommended for maintaining the $\mathrm{C} / \mathrm{N}$ ratio in the semi-arid Karapınar region. For this reason, the current level of $4 \%$ forage crops production needs to be increased to $12 \%$ within more than 200.000 ha of cultivated land of Karapınar. While the natural pastures under preservation had the highest organic carbon content, the lowest values were obtained from overgrazed pastures. More than 120 natural plant species were identified during the species-count in the study area, which is an indication of the richness of the pastures in a semi-arid environment. Hence, it has been concluded that any grazing of more than 1.4 sheep per hectare would exceed the self-renewal process of plants, decrease organic input to soil and trigger desertification, which was halted following 60 years of protection.
\end{abstract}

Keywords: soil, pasture area, biomass, degraded area, carbon sequestration

*e-mail: gbuyuk@adiyaman.edu.tr 


\section{Introduction}

Soil carbon storage is a vital ecosystem service resulting from interactions of ecological processes. Human activities affecting these processes can lead to carbon loss or improved storage [1]. Organic matter is a key component of soil that affects its physical, chemical, and biological properties, contributing greatly to its proper functioning, on which human societies depend. Benefits of soil organic matter (SOM) include improvement of soil quality through increased retention of water and nutrients, resulting in greater productivity of plants in natural environments and agricultural settings.

Plant diversity strongly influences ecosystem functions and services such as soil carbon storage. However, the mechanisms underlying the positive effects of plant diversity on soil carbon storage are not well understood [2]. In general, the amount of carbon stored in the soil represents a balance between plant growth and root production, root exudates and their microbial decomposition [3]. The increase in carbon sequestration with plant diversity reflects higher net primary production [4]. Soil organic carbon plays an important role both in terms of atmospheric carbon resource and bringing carbon back to soil. In a study conducted in 2016 by [5] aiming to reclaim degraded areas in China, it was reported that perennial legumes have no contribution in increasing soil carbon stock in semi-arid areas to improve the soil carbon cycle. In contrast, it has been reported that natural vegetation on soil organic carbon is significantly higher than cultivated crops $[6,7]$.

"Wind Erosion Planning and Operation Group Chief Engineering", established as an affiliate of the Regional Directorate of Soil and Water Conservation and Irrigation Service in Konya, commenced its regional combat against wind erosion in 1962, initially through survey/plan studies, followed by more comprehensive works covering an area of 16.000 hectares in 1963. Sand dune prevention works were completed in 1972. This study has been conducted with the purpose of monitoring the changes in soil quality following the desertification works in the Karapınar district of Konya closed basin that lasted for almost 60 years, and in particular the purpose was to determine soil organic carbon sequestration and vegetation interaction in different land uses.

\section{Materials and Methods}

\section{Material}

The study area, covering 16.000 ha, is located within the Konya Closed Basin and is severely subjected to wind erosion and facing desertification threat. The Erosion Protection Area comprises 4 different land types, namely the Stabilized Sand Dune Zone (4300 ha), the Moving Coastal Dune Zone (4000 ha) the Erosion-Sensitive Flat Lands (3200 ha), and the Rocky Hill Zone (1500 ha) [8]. Karapınar is in the center of approximately a $4000 \mathrm{~km}^{2}$ project area (Fig. 1), which also includes the Ereğli and Karaman regions. Four measurements for soil and vegetation were undertaken in 2010-2011 and 2016-2017.

The majority of the study area is located within the Karapınar District borders. The region is dominated by continental climate that is warm and dry during summer and cold and rainy in winter. Average precipitation in Karapınar is $283.9 \mathrm{~mm} / \mathrm{year}$, which is far below the national average of $643 \mathrm{~mm} /$ year. Free water surface evaporation is around $2000 \mathrm{~mm}$ in the region [9]. The highest level of precipitation in the area is seen in spring $(40 \%)$, followed by winter $(38 \%)$, fall $(15 \%)$ and summer (8\%). Low precipitation during the summer months is accompanied by severe levels of evaporation.

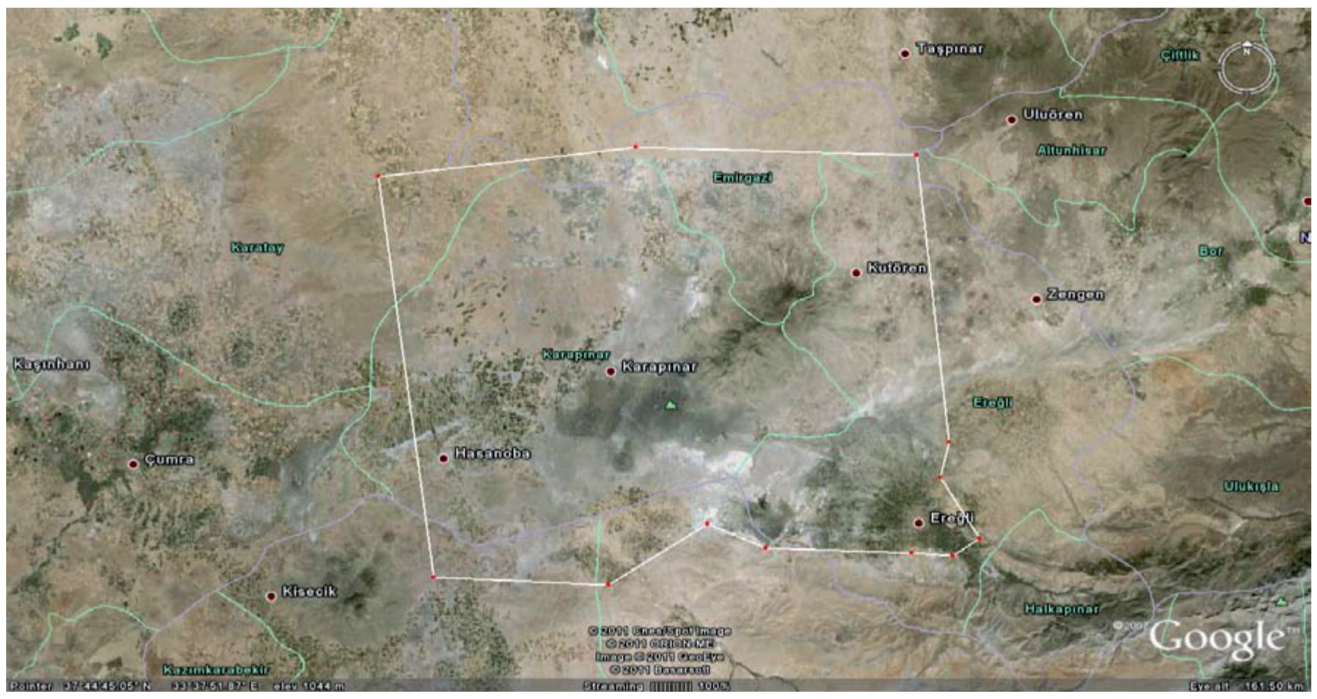

Fig. 1. Project area location map. 
Annual average temperature is $11^{\circ} \mathrm{C}$ in Karapinar, where the coldest month is January with an average temperature of $-0.4^{\circ} \mathrm{C}$, and the warmest is July at $22.6^{\circ} \mathrm{C}$ [10]. June, July and August have high temperatures in the study area when water is required for agricultural products.

\section{Method}

\section{Soil Classification}

Soil quality monitoring in the Karapınar region was carried out by [11] in 1998, followed by other studies until 2009 and continued on until 2015 [12]. Soil quality is defined through measuring the changes of physical, chemical and biologic characteristics of soil. Analyses have been performed to identify the changes in soil quality in agricultural lands used for traditional agriculture and ecological agriculture. Soil samples from Calcaric Cambisol [13] have been taken, which is widely distributed in the region (35\%). Other soil samples, like Leptic Cambisol with its higher clay content (33\% vs. $40 \%$ ) and relatively low lime content (16\% vs. $8 \%)$, have been taken from Ambar village south of Karapınar.

Soil samples were mainly collected from surface horizons as no changes were identified in subsurface horizons as profile development is not advanced to deep soil. Subsurface horizons have also been sampled as the project area expanded during the study [14]. Throughout the whole project period, a total of 1200 samples from 520 points have been analyzed.

\section{Soil Organic Carbon and Humification Rate}

Soil organic carbon was measured in the Karapinar Erosion conservation Area from 2000 to 2015 [12], as soil organic carbon is one of the main indicators for soil quality [15]. Land use within the study area can be categorized into four groups: natural pastures (45-50\%), field crop agricultural areas (15-20\%), horticulture crop agricultural areas (10-15\%) and natural areas mostly containing rocks and sinkholes.

Soil organic carbon measurement was conducted within a week following sampling in order to reduce the effects of organic carbon decomposition processes such as microbial degradation, oxidation and volatilization [16]. Bulk density (BD) is required to calculate soil organic carbon stocks in tons of carbon per hectare. Bulk density is the dry weight of a known volume of soil. It can be taken using a core, exhaust tube or pipe hammered into soil for a given depth [17]. Along with wet decomposition [18], loss on ignition at the $500^{\circ} \mathrm{C}$ method has also been used for organic matter analyses at places with volcanoclastic materials due to the possibility of some volcanic minerals (pyroxene etc.) dissolving in acid solution and impacting the solution color [19].
Humic and fulvic acid analyses have been performed on air-dried $0,5 \mathrm{~g}$ soil samples described by [20]. The humification rate was calculated by the equation:

$$
H R=\frac{H A+F A}{\operatorname{Org} \cdot C} \times 100
$$

\section{Biomass Measurements and Grazing Carrying Capacity}

Organic material production measurement of plants collected from 27 locations at $1 \times 1 \mathrm{~m}$ plots were undertaken after drying at $80^{\circ} \mathrm{C}$ for 2 hours (Table 1). The measurements being taken when the plants were wet led to several errors [21 and 22], and organic material content of the plants was employed following the drying of the plants. Dried plant material and residues (leaves, flowers, etc.) belong to the sampling year in which both were collected. The color of the material from previous years was black-grey due to decomposition, thus materials with light yellow to yellow were collected for measurement [23].

Samples with 3 parallels collected from 104 points were distributed in Karaman, Ereğli and Karapınar. These areas contain preserved zones of Karapınar Erosion Control Station as well as areas preserved by TEMA (the Turkish Foundation for Combating Erosion Reforestation and the Protection of Natural Habitats, since 2006) and therefore there is a possibility to compare them with those under the pressure of grazing.

The carrying capacity of Karapınar Region grazelands is calculated by using an IOS application developed using the Animal Unit Month (AUM) method (https://apps.apple.com/us/app/ndsu-grazing-calculator/ id1213526389). Carrying capacity is the number of animal units that can be grazed for a specific time period, which is expressed as the number of available animal unit months. [24] described the formulas used in the IOS application in detail.

\section{Results and Discussion}

\section{Vegetation Cover}

The study area comprises the Karapınar region's grassland, which reflects central Anatolia's pasture vegetation cover, and it has been chosen for being relatively distant from human pressure due to relatively less grazing per unit area. Stockbreeding-based income was highly dominant in the region until the 1990s. The annual biomass and variety level of the natural vegetation cover against climate change reflects the quality of vegetation cover. This is another indication that the pastures in the region are highly sensitive. But in contrast, it has also been observed that carbon 
Table 1. Common pasture plants in the Karapınar region, Central Anatolia, Turkey.

\begin{tabular}{|c|c|c|c|}
\hline Spices & Local name & $\begin{array}{l}\text { Avail- } \\
\text { ability }\end{array}$ & $\begin{array}{l}\text { Domi- } \\
\text { nance }\end{array}$ \\
\hline Stipa holosericea & & + & 3 \\
\hline Salvia cryptanta & Tapir & + & 2 \\
\hline $\begin{array}{c}\text { Astragalus } \\
\text { microcephalus }\end{array}$ & Geven & + & 2 \\
\hline Centaurea depressa & $\begin{array}{l}\text { Peygamber } \\
\text { çiçeği }\end{array}$ & + & 1 \\
\hline Bromus tectorum & & 1 & 1 \\
\hline Scorzonera mollis & & + & 1 \\
\hline Scabiosa argentea & Uyuz otu & + & 1 \\
\hline Echinops ritro & Eşek dikeni & + & 1 \\
\hline Lappula barbata & & + & 1 \\
\hline Anthemis tinctoria & Papatya & + & 1 \\
\hline Poa bulbosa & & + & 1 \\
\hline Isatis tinctoria & Çivit otu & + & 1 \\
\hline Glassium filavum & & + & 1 \\
\hline Xeranthemum annuum & & + & 1 \\
\hline Prangos meliocarpa & & + & 1 \\
\hline Velezia rigida & & + & 1 \\
\hline Cousinia birandiana & & + & 1 \\
\hline Peganum harmala & Üzerlik otu & + & 1 \\
\hline Eremopyrum orientalis & & + & 1 \\
\hline Salsola kali & Soda otu & + & 1 \\
\hline Cynodon dactylon & Ayrık & + & 1 \\
\hline Ziziphora taurica & & + & 1 \\
\hline Artemisia campeste & & + & 1 \\
\hline Astragalus lycius & Geven & + & 1 \\
\hline Papaver argomena & Gelincik & + & 1 \\
\hline
\end{tabular}

accumulation of soil under the astralagus plant was 26.2 ton $\mathrm{C} / \mathrm{ha}$, and this is thought to be associated to the fact that the astralagus plant protects soil from wind erosion and therefore the layer with accumulated organic matter is not affected by erosion. Astralagus is a perennial, thorny herbaceous plant bunched in the shape of a pillow and protecting a great amount of area against moving [25]. The most common types of plants in the region are listed in Table 1. The plants observed in the area, as also concluded by previous studies in the region, are under the threat of overgrazing.

\section{Soil Organic Carbon}

The lowest and highest organic carbon content in the area have been observed in natural pastures. Pastures under preservation yielded the highest organic carbon content, while overgrazed pastures have the lowest values.

\section{Organic Carbon Content of Field Crop Agricultural Areas}

Field crops are being grown in the study area for several thousands years. The main products grown are wheat, barley, clover, trefoil, and sugar beet as well as corn, the latter having become increasingly popular during the past decade. The reason for providing a general organic carbon value is due to growing different products in the measurement areas during the long-lasting observation period. However, with regards to field crops, organic carbon content in irrigated farming with higher levels of fertilizer has been found to be lower than that of dry farming. The main reason for this is the fact that higher levels of nitrogen induce the decomposition of organic matter in soil [26]. Furthermore, organic carbon content in clover fields with irrigated farming has been measured to be relatively higher $(0,63-0,81 \%$ organic carbon). The same value has been reported in many other sources related to clover farming [27]. But having said this, it must be

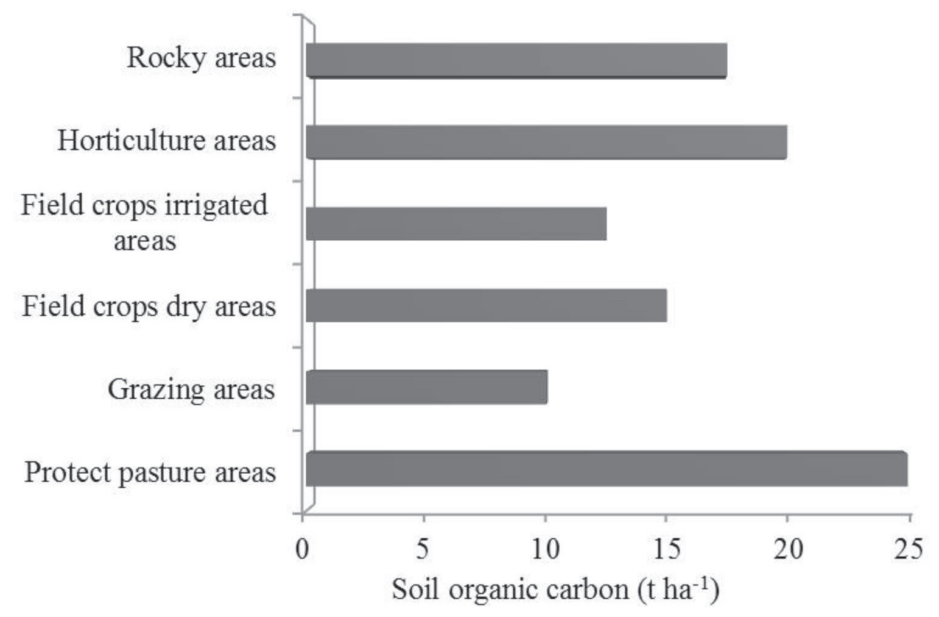

Fig. 2. Soil organic carbon content in different land types. 
kept in mind that high water demand of clover has a negative impact on the environment because irrigation water in the region is obtained from groundwater sources.

\section{Organic Carbon Content of Horticultural Crops Areas}

Horticulture is highly common in Akçaşehir and southern parts of Ereğli, where apple and cherry are the most-grown products. No significant difference has been observed between the measurements taken from both areas. However, organic carbon content in horticultural areas was relatively higher than the irrigated fields (Fig. 2) as nitrogen fertilizers are extensively applied in irrigated fields, which rapidly cause the decomposition of organic matter.

\section{Rocky, Sinkhole Areas}

Pastures and rocky areas with shallow soils $(<15 \mathrm{~cm})$ are categorized as miscellaneous areas and the analyses performed in such areas yielded highly varying results. However, generally organic carbon levels in these areas were higher than the irrigated field crop areas. But the value per hectare is still low if the amount of rocks and stones are to be taken into account (Fig. 2).

It is a known fact that global climate change is negatively affected by greenhouse gas emissions. New land use methods are being developed to reduce such negative effects of greenhouse gasses [28]. In this sense, defining the highest soil organic sequestered land use in Karapınar with unfavorable climate (low precipitation) and soil (shallow, high lime, low organic carbon) conditions will play an important role in the efforts related to combating desertification. During our field studies, the most appropriate carbon capture method was sought not only by focusing on soil organic carbon value but also on the irrigation water used, fertilizer consumption and land cultivation.
Accordingly, the highest level of soil organic carbon was observed in pasture areas under preservation. Clover cultivation areas have a relatively higher level of organic carbon, but their extreme use of water is a negative question mark for sustainable use of groundwater resources. Thus, rain-fed farming practices are observed to be more suitable both for water management and organic carbon sequestration.

\section{Humic and Fulvic Acid Values}

Humin compounds are the form of organic matter that stays longer in soil and they are calcualated by measuring humic and fulvic acid in soil [29, 30]. Analyses have been conducted in soils in Meke, Kartan, and Günağılı series in a pasture in Ereğli pasture, and Vahapobası and Apak preservation areas and in an apple orchard in Akçaşehir (Table 2).

Analyses have concluded that the highest level of huminization of organic material was in Apak and Günağ 11 preservation areas. It was followed by the pasture in Ereğli (Table 2). Even though the organic material level in Apak is lower than that in Meke and Günağllı series, the high level of humin is most probably because the soil in Apak contains high levels of smectitic clay, which holds more organic cations than finely textured soils $[31,32]$. Similar to the Apak series, the level of clay in the apple orchard in Akçaşehir is also high, but organic matter is relatively low and apple orchards are fertilized by nitrogen, leading to rapid degradation of organic matter, and this is thought to cause a low humin ratio.

In conclusion, despite all the preservation efforts in the study area, the humification ratio of organic matter is low and this is an indication of vulnerability of the soils to mismanagement.

\section{Biomass Measurements}

Biomass in pastures should not only be considered in terms of stockbreeding activities but also erosion

Table 2. Humic and fulvic acid content, humification rates* and some soil properties of the studied soils.

\begin{tabular}{|c|c|c|c|c|c|c|}
\hline \multirow{2}{*}{ Sample Site } & Organic Carbon (OC) & Humic acid (HA) & Fulvic acid (FA) & Humification & Clay \\
\cline { 2 - 7 } & \multicolumn{5}{|c|}{$\%$} & \multicolumn{4}{c|}{22,73} & 1 \\
\hline Meke & 1,1 & 0,11 & 0,14 & 36,92 & 11 \\
\hline Kartan & 0,65 & 0,1 & 0,14 & 39,06 & 6 \\
\hline Günağılı & 0,64 & 0,12 & 0,13 & 37,74 & 14 \\
\hline Ereğli Grazeland & 0,53 & 0,08 & 0,12 & 35,94 & 6 \\
\hline Vahapobası Protected Area & 0,64 & 0,09 & 0,14 & 45,33 & 25 \\
\hline Apak Protected Area & 0,75 & 0,15 & 0,19 & 38,10 & 26 \\
\hline Akçaşehir Apple Orchards & 0,63 & 0,11 & 0,13 & & \\
\hline
\end{tabular}

*Humification rate was measured from a percentage of the amount of humic acid and fulvic acid with total soil organic carbon 
Table 3. Biomass values taken from points represented in the study area.

\begin{tabular}{|c|c|c|c|c|c|}
\hline \multirow{3}{*}{ Sample No. } & \multirow{3}{*}{ Sampling site } & \multicolumn{4}{|c|}{ Average dry weight* } \\
\hline & & 2010 & 2011 & 2016 & 2017 \\
\hline & & \multicolumn{4}{|c|}{$\mathrm{g} / \mathrm{m}^{2}$} \\
\hline 1 & Saline field N. Karapınar & 156.62 & 162.2 & 159.93 & 165.5 \\
\hline 2 & Emirgazi & 39.80 & 44.26 & 41.80 & 45.5 \\
\hline 3 & Yağmapınar & 85.52 & 88.15 & 89.73 & 90.4 \\
\hline 4 & Sakızlı & 84.42 & 84.56 & 87.43 & 88.8 \\
\hline 5 & Yeşilyurt mountainous & 116.45 & 123.5 & 120.47 & 125.4 \\
\hline 6 & Vahapovas1 conservation site & 72.56 & 79.65 & 77.40 & 81.8 \\
\hline 7 & Günağılı erosion control station & 75.6 & 74.80 & 78.5 & 76.6 \\
\hline 8 & Kamışlı kuyu & 66.53 & 69.65 & 69.83 & 71.0 \\
\hline 9 & Gölören mountainous & 94.85 & 96.54 & 98.10 & 99.8 \\
\hline 10 & Akçaşehir & 94.20 & 98.63 & 95.10 & 101.6 \\
\hline 11 & İnobas1 & 81.25 & 84.59 & 83.60 & 87.6 \\
\hline 12 & Akgöl Lake banks & 93.24 & 94.25 & 95.23 & 96.7 \\
\hline 13 & Kartan erosion control station & 75.64 & 75.20 & 78.4 & 78.2 \\
\hline 14 & Meke lake & 103.58 & 94.56 & 105.7 & 98.6 \\
\hline 15 & Apak & 75.40 & 78.45 & 78.6 & 82.5 \\
\hline 16 & Besci & 65.12 & 60.20 & 66.8 & 63.3 \\
\hline 17 & Ambar & 74.56 & 65.14 & 76.3 & 68.1 \\
\hline 18 & Kesmez & 63.35 & 58.61 & 66.45 & 61.2 \\
\hline 19 & Kayalı & 74.80 & 75.84 & 79.4 & 80.3 \\
\hline 20 & Islik & 59.54 & 64.42 & 62.7 & 66.4 \\
\hline 21 & Yenikuyu & 68.71 & 62.57 & 70.7 & 67.4 \\
\hline 22 & Gölören Forests & 73.45 & 73.20 & 77.9 & 74.6 \\
\hline 23 & Kokarkuyu & 88.16 & 84.60 & 91.3 & 87.9 \\
\hline 24 & Kavuklar & 78.56 & 86.25 & 81.0 & 89.7 \\
\hline 25 & Hotamış & 74.68 & 75.80 & 77.8 & 79.6 \\
\hline 26 & Hasanoba & 83.68 & 85.49 & 88.1 & 89.4 \\
\hline 27 & Basaltic outcrops erosion station & 70.26 & 75.34 & 75.6 & 78.4 \\
\hline
\end{tabular}

*The values are average of three point

protection [33], and organic carbon capture in biomass measurements, the lowest values have been observed in the Kartan Erosion Control Area, while the highest level was obtained in Ambar, where the clay content is approximately $5-10 \%$ higher (Table 3 ). In the meantime, as pastures are shifted to agricultural lands the pasture areas are getting smaller in size, this is creating an even higher pressure of grazing. However, 2015 values were higher than 2016 (302 mm) values - most probably due to high levels of precipitation, which were more than $330 \mathrm{~mm}$ in 2015 and close to $300 \mathrm{~mm}$ in 2016. Plants in pastures have been reported by several studies to be highly beneficial against erosion, which was also determined in this study. The preserved lands vegetation cover density and plant spices change in 6 years during the TEMA Project is highly important in terms of revealing the plants' potential in creating a new vegetation cover, i.e., natural succession [34].

Therefore, in the overgrazed areas in the study field, astralagus species need to be protected and not used as fuel during winter months by locals or cleared for agricultural purposes. Furthermore, species yielding high levels of biomass, such as Minuartia Anatolica, Erysimum Crassipes, Noena Mucronata, 
Table 4. Plant species in working field pastures.

\begin{tabular}{|c|c|c|c|c|c|}
\hline No & Plant type & No & Plant type & No & Plant type \\
\hline 1 & Acantholimon venustum & 42 & Cerastium dichotumum & 84 & Ononis spinoza \\
\hline 2 & Acantholimon ecunus & 43 & Chenopodium album & 85 & Onosma tauricum \\
\hline 3 & Achillea wilhemsii & 44 & Cochia prostata & 86 & Orobajhae minor \\
\hline 4 & Adonis filemmea & 45 & Convolvulus arvensis & 87 & Papaver argomena \\
\hline 5 & Ajuga chamaepytis & 46 & Couisinia birandiana & 88 & Peganum harmala \\
\hline 6 & Alcanna orientalis & 47 & Cynodon dactylon & 89 & Petrosimonia brachiata \\
\hline 7 & Alhagi pseudoalhagi & 48 & Dianthus arinitus & 90 & Phleum exaratum \\
\hline 8 & Allium staminoum & 49 & Echinophora capitata & 91 & Pinus nigra spp \\
\hline 9 & Alopecurus litoralis & 50 & Echinops ritro & 92 & Poa bulbosa \\
\hline 10 & Alyssum linifolium & 51 & Elleagnus angustifolius & 93 & Populus nigra \\
\hline 11 & Amegyladus orientalis & 52 & Ephedra major & 94 & Prangos meliocarpa \\
\hline 12 & Amigylalus weebi & 53 & Eradium cicutarium & 95 & Prangos meliocarpa \\
\hline 13 & Anchusa italica & 54 & Eremopyrum orientalis & 96 & Rhamnus Oleoides \\
\hline 14 & Anchusa lycius & 55 & Eryngium campeste & 97 & Salicornia europea \\
\hline 15 & Anchusa leptophlia & 56 & Erysimum crassipes & 98 & Salix alba \\
\hline 16 & Androsache maxima & 57 & Erysimum crassipes & 99 & Salsola kali \\
\hline 17 & Anthemis tictoria & 58 & Euphorbia macroclada & 100 & Salvia crptanta \\
\hline 18 & Anthemis cretica & 59 & Festuca ovina & 101 & Saphonaria mesogitana \\
\hline 19 & Apera intermedia & 60 & Festuca valeciaca & 102 & Saponaria mesogitaanus \\
\hline 20 & Artemisia santonicum & 61 & Floem longipetala & 103 & Scabiosa argentea \\
\hline 20 & Artemisia campeste & 62 & Fumaria anatolica & 104 & Sicablosa argentea \\
\hline 21 & Asperula stricta & 63 & Glaccium filavum & 105 & Sicorzonera mollis \\
\hline 22 & Astralagus lydius & 64 & Gypsophila pilosa & 106 & Silene subconica \\
\hline 23 & Astralagus lycius & 65 & Halecnemum strabilaceum & 107 & Sinapis arvensis \\
\hline 24 & Astralagus microcephalus & 66 & Haplofillum theoides & 108 & Stipa barbata \\
\hline 25 & Astralagus santonicum & 67 & Helicrisum plicatum & 109 & Stipa holosericea \\
\hline 26 & Boreava orientalis & 68 & Heliotropium dolosum & 110 & Teucrium polium \\
\hline 27 & Briza humilis & 69 & Hernaria incano & 111 & Teucrium orientalis \\
\hline 28 & Bromus tectorum & 70 & Hipecoum procumbens & 112 & Thymus spyleus \\
\hline 29 & Bromus japonicus & 71 & Hordeum murinum & 113 & Tragopogon latifolia \\
\hline 30 & Bromus squarrasus & 72 & Isatis floribunda & 114 & Trigonella monspeliaca \\
\hline 31 & Bromus tomentellus & 73 & Isatis tinctoria & 115 & Trigonella plicata \\
\hline 32 & Bromus tomentellus & 74 & Kardus nutans & 116 & Valeriannella coronata \\
\hline 33 & Bupleurum arundinaceus & 75 & Koeleria cristata & 117 & Velecia rigida \\
\hline 34 & Bupleurum subuniflorum & 76 & Lappula barbata & 118 & Verbascum songaricum \\
\hline 35 & Camphorosma monspelica & 77 & Marribium parviflorum & 119 & Verbascum cherianthifolium \\
\hline 36 & Cedrus libani & 78 & Minuartia anatolica & 120 & Vinca harbacea \\
\hline 37 & Centaurea virgata & 79 & Minuartia hamata & 121 & Wiedmanniana orientalis \\
\hline 38 & Centaurea depressa & 80 & Nardurus nutans & 122 & Xeranthemum annum \\
\hline 39 & Centaurea pulchella & 81 & Noena mucronata & 123 & Ziziphora taurica \\
\hline 40 & Centaurea grabifolia & 82 & Onobrychis tourneforti & & \\
\hline 41 & Centaurea solstitialis & 83 & Onobrychis armena & & \\
\hline
\end{tabular}


Centaurea Virgata and Bromus Tectorumun, need to be reproduced in genetic banks and seeded to the pastures in unprotected areas for reclamation. This will provide a great contribution in capturing organic carbon and erosion prevention (Table 4).

Overgrazing during the 1960 s led to the perishing of vegetation cover, which in turn led to erosion. It is therefore important to protect pastures while grazing local sheep flocks. Thus the grazing of more than 1.4 sheep per hectare calculated by an IOS application developed on AUM would be exceeding the self-renewal process of plants. It has accordingly been calculated that the current level of $4 \%$ forage crop cultivation needs to be increased to $12 \%$ for meeting local herders feeding demand in more than 200.000 ha cultivated land of the study area.

Therefore, it is suggested that overgrazed areas in the proximity of agricultural areas can be rented to local farmers on the condition that they cultivate low water demanding forage crops such as vetch. Unfortunately, it has been observed that these areas are planted with corn, although generating more revenue, crop cultivation degrades soil quality by excess irrigation, tillage and fertilization.

In addition, overgrazing - particularly in the Kesmez-Ereğli and Vahapobası Ayranc1 regions - has led to the astragalus plant becoming dominant, and this causes difficulties for sheep breeders due to the low feeding capacity of astralagus. These areas need to be reclaimed as soon as possible, particularly with bromus species because cultivating plants consuming high water will not conform to the hydrology balance of the area. More than 120 different plants have been observed in the study area, which is an indication of the richness of the pastures even in a semi-arid continental climate (Table 4).

\section{Conclusions}

Soil organic carbon in a study area is below 14.5 ton $\mathrm{C} / \mathrm{ha}$, although strict conservation studies have been ongoing for almost 60 years. This value has a negative impact on many processes regarding the maintenance of soil quality. Increasing the amount of organic matter will help sequester the prominent atmospheric greenhouse gas carbon dioxide in soil. With this in mind, fallow, the use of high levels of nitrogen and over-irrigation must be avoided, and the cultivation of leguminous plants such as vetch should be encouraged in the region. Moreover, the sustainable use of pasture lands is of utmost importance due to the more than 120 natural plant species that all contribute to soil organic carbon pools as well as being indicators of the biodiversity in arid conditions This vegetation richness also revealed that priority is given to sustainable management even in a semi-arid land, and natural resources can support human demands. Thus, the Karapinar region's soil organic carbon source seems to be pasture plants that need special protection and a production approach. In addition, these plants may also serve as genetic sources for future drought-resistant crop production for food security for both humans and animals.

\section{Acknowledgements}

The authors wish to express their profound thanks to Prof. Dr. Selim Kapur for his invaluable criticism. We also express our gratitude to the TEMA Foundation, the MITSUI Environmental Fund and ILEK Project RIHN in Japan for funding our study.

\section{Conflict of Interest}

All the authors declare no conflict of interest.

\section{References}

1. BENDER S.F., WAGG C., VAN DER HEIJDEN M.G. An underground revolution: biodiversity and soil ecological engineering for agricultural sustainability. Trends in Ecology \& Evolution, 31 (6), 440, 2016.

2. LANGE M., EISENHAUER N., SIERRA C.A., BESSLER H., ENGELS C., GRIFFITHS R.I., MELLADO-VAZQUEZ P.G., MALIK A.A., ROY J., SCHEU S., STEINBEISS, S., THOMSON B.T., TRUMBORE S.E., GLEIXNER G. Plant diversity increases soil microbial activity and soil carbon storage. Nature communications, 6, 6707, 2015.

3. RUMPEL C., CHABBI A. Plant-Soil Interactions Control CNP Coupling and Decoupling Processes in Agroecosystems With Perennial Vegetation. In Agroecosystem Diversity (pp. 3-13). Academic Press. 2019.

4. JHARIYA M.K. Vegetation ecology and carbon sequestration potential of shrubs in tropics of Chhattisgarh, India. Environmental monitoring and assessment, 189 (10), 518, 2017.

5. GUAN X.-K., TURNER N.C., SONG L., GU Y.-J., WANG T.-C., LI F.-M. Soil carbon sequestration by three perennial legume pastures is greater in deeper soil layers than in the surface soil, Biogeosciences, 13, 527, doi:10.5194/bg-13527. 2016.

6. KAPUR S., AKÇA E., ZUCCA C., BERBEROĞLU S., and MIAVAGHI, S. R. Anthroscapes: A Robust Basis for Mapping Land Quality and Sustainable Land Use Patterns. In Eastern Mediterranean Port Cities (pp. 63-77). Springer, Cham. 2019.

7. DOS SANTOS C.A., REZENDE C.D.P., PINHEIRO É.F.M., PEREIRA J.M., ALVES B.J., URQUIAGA S., BODDEY R.M. Changes in soil carbon stocks after land-use change from native vegetation to pastures in the Atlantic forest region of Brazil. Geoderma, 337, 394, 2019.

8. PALTA Ç., KIRTIŞ F., OKUR O., OKUR M., KARADAVUT U., ÇARKACI D.A., ŞIMSSEKLI N. The Karapinar Case in Wind Erosion Combatting. I. National Drought and Desertification Symposium 16-18 Junen 2009, Konya, 78-83. 
9. TÜRKMEN Ö., SEYMEN M., PAKSOY M., ARISOY H., KURTAR E.S. Potential of vegetable and possibilities of improvement in Ereğli, Karapınar, Emirgazi and Halkapınar districts of Konya province. Manas Journal of Agriculture Veterinary and Life Sciences 7.2. 2017.

10. YILMAZ M. Environmental Problems Caused by Ground Water Level Changes around Karapinar. Ankara University, Journal of Environmental Sceinces 2 (2), 145, 2010.

11. AKÇA E. Determination of the soil development in Karapinar erosion control station following rehabilitation. University of Çukurova, Institute of Basic and Applied Sciences (Doctoral dissertation, Doctoral Thesis. 195 P. Adana, Turkey). 2001.

12. AKÇA E., TAKASHI K., SATO T. Development and success, for whom and where: the central Anatolian case. In Land Restoration (pp. 533-541). Academic Press. 2016.

13. IUSS WORKING GROUP WRB. World reference base for soil resources 2006. $2^{\text {nd }}$ edition. World Soil Resources Reports No. 103. FAO, Rome. 2015.

14. AKÇA E., NAGANO T., TAKASHI K., İSFENDIYAROGLU S., UZBILEK M., PALTA Ç., OKUR O., OKUR M., ŞIMŞEKLI N., KAPUR S. Determination of water exploitation in Karapınar, Turkey: An Arid Region Experience. $3^{\text {rd }}$ International Conference Water Science and Technology with Emphasis on Water \& Climate. 16-19 October 2008.

15. WANI S.P., CHANDER G., SAHRAWAT K.L., RAO C.S., RAGHVENDRA G., SUSANNA P., PAVANI M. Carbon sequestration and land rehabilitation through Jatropha curcas (L.) plantation in degraded lands. Agriculture, ecosystems \& environment, 161, 112, 2012.

16. SCHUMACHER B.A. Methods for the determination of total organic carbon (TOC) in soils and sediments. Ecological Risk Assessment Support Center, 1-23. 2002.

17. https://www.agric.wa.gov.au/soil-carbon/measuring-andreporting-soil-organic-carbon. 16/06/2019.

18. CHARLES M.J., SIMMONS M.S. Methods for the determination of carbon in soils and sediments: A review. Analyst. 111, 385, 1986.

19. SPARNAAIJ L.D, KOEHORST-VAN PUTTEN H.J., BOS I. Component analysis of plant dry matter production: A basis for selection of breeding parents as illustrated in carnation. Euphytica 90, 183, 2018.

20. PUTRA M.J.N.F.I.A., SOEMARNO S., SUNTARİ R. Humification degree and its relationship with some soil physical characteristics on robusta coffee (Coffea canephora) plantation. Journal of Degraded and Mining Lands Management, 3 (4), 649, 2016.

21. OVERMAN A.R. An expanded growth model for grasses. Commun. Soil Sci. Plant Anal. 29, 67, 1998.

22. BARBOUR M. Age and space distribution of the desert shrub Larrea divaricata. Ecology 50, 679, 1969.
23. BARR C.A. Jewels of the plains: wildflowers of the Great Plains grasslands and hills. U of Minnesota Press, 2015.

24. MEEHAN M., BRUMMER F., SEDIVEC K., and PRINTZ F. Determining Carrying Capacity and Stocking Rates for Range and Pasture in North Dakota. https://www.ag.ndsu. edu/publications/livestock/determining-carrying-capacityand-stocking-rates-for-range-and-pasture-in-north-dakota/ r1810.pdf.

25. SOMMER R., PAUL B.K., MUKALAMA J., KIHARA J. Reducing losses but failing to sequester carbon in soils - the case of Conservation Agriculture and Integrated Soil Fertility Management in the humid tropical agroecosystem of Western Kenya. Agriculture, ecosystems \& environment, 254, 82, 2018.

26. HANSEN E.M., ERIKSEN J. Nitrate leaching in maize after cultivation of differently managed grass-clover leys on coarse sand in Denmark. Agriculture, Ecosystems \& Environment, 216, 309, 2016.

27. ROGELJ J., DEN ELZEN M., HÖHNE N., FRANSEN T., FEKETE H., WINKLER H., SCHAEFFER R., SHA F., RIAHII K., MEINSHAUSEN M. Paris Agreement climate proposals need a boost to keep warming well below $2^{\circ} \mathrm{C}$. Nature, 534 (7609), 631. 2016.

28. POLAT O., POLAT S., AKÇA E. Küresel Isınmada Ormanların Karbon Tutulumuna Etkisi: Tarsus-Karabucak Örneği. Kahramanmaraş Sütçü İmam Üniversitesi Doğa Bilimleri Dergisi, Özel, (313-319). 2011.

29. PENA-MÉNDEZ E.M., NOVOTNÁ K., GAJDOŠOVÁ D., GONZÁLEZ V., HAVEL J. Characterization of humic substances of different origin by means of mass spectrometry and neural networks. Chemosphere, 68 (11), 2047, 2007.

30. PAUL E. A. The nature and dynamics of soil organic matter: plant inputs, microbial transformations, and organic matter stabilization. Soil Biology and Biochemistry, 98, 109, 2016.

31. LI L., HUANG W.L., PENG P., SHENG G.Y., FU J.M. Chemical and molecular heterogeneity of humic acids repetitively extracted from a peat. Soil Sci. Soc. Am. J. 67 (3), 740, 2003

32. ALTIERI M.A. Agroecology: the science of sustainable agriculture. CRC Press. 2018.

33. ZOU L., SUN Y., CHE S., YANG X., WANG X., BOSCH M., WANG Q., LI H., SMITH M., YUAN S., PERRY Z., ZOU, H. Porous organic polymers for post-combustion carbon capture. Advanced Materials, 29 (37), 170022, 2017.

34. BÜYÜK G., ZUCCA C., AKÇA E. Effect of animal manure on decreasing chemical fertilizer use in degraded farm fields in semiarid region of Central Turkey. Biharean Biologist, 11 (1), 48. 2017. 
